\title{
ARTICLE
}

\section{Aerobic and anaerobic enzyme activity in the hake Merluccius gayi gayi related to the Oxygen Minimum Zone off central-southern Chile}

Actividad enzimática aeróbica y anaeróbica de la merluza común Merluccius gayi gayi, relacionada con la Zona de Mínimo Oxígeno de Chile centro-sur

\section{Luisa M. Saavedra ${ }^{1 *}$, Renato A. Quiñones ${ }^{2,3}$ and Rodrigo R. González ${ }^{3,4,5}$}

${ }^{1}$ Center for the Study of Multiple-Drivers on Marine Socio-Ecological Systems (MUSELS), Universidad de Concepción, Barrio Universitario s/n, Concepción, Chile. *lsaavedr@udec.cl

${ }^{2}$ Interdisciplinary Center for Aquaculture Research (INCAR), Universidad de Concepción, O’Higgins 1695, Concepción, Chile ${ }^{3}$ Departamento de Oceanografía, Facultad de Ciencias Naturales y Oceanográficas, Universidad de Concepción, Casilla 160C, Concepción, Chile

${ }^{4}$ Unidad de Biotecnología Marina, Facultad de Ciencias Naturales y Oceanográficas, Universidad de Concepción, Casilla 160C, Concepción, Chile

${ }^{5}$ Centro COPAS Sur-Austral, Facultad de Ciencias Naturales y Oceanográficas, Universidad de Concepción, Casilla 160C, Concepción, Chile

\begin{abstract}
Resumen.- El Sistema de Corrientes de Humboldt de la costa de Chile posee una Zona de Mínimo Oxígeno (ZMO) entre 30 y $250 \mathrm{~m}$ de profundidad, con concentraciones de oxígeno $<0,5 \mathrm{ml} \mathrm{L}^{-1}$. Las mayores densidades de merluza Merluccius gayi gayi se asocian a esta zona, sugiriendo que posee adaptaciones metabólicas para permanecer en ella. Se estimó el potencial aeróbico y anaeróbico de esta especie demersal mediante la medición de enzimas metabólicas claves y del sistema de transporte de electrones (ETS) en diferentes tejidos (músculo blanco, corazón, cerebro e hígado). La actividad de la enzima citrato sintasa (CS) y de la ETS fueron mayores en el cerebro y corazón, confirmando la predominancia del metabolismo aeróbico en los órganos vitales diferentes al músculo. La actividad promedio de la enzima anaeróbica lactato deshidrogenasa (LDH) fluctuó entre $55 \pm 17,5$ and $263 \pm 79$ UI $\mathrm{g}^{-1} \mathrm{ww}$, siendo menor en el corazón y cerebro. Esta baja actividad de LDH y una alta razón MDH/LDH en estos órganos vitales indican que ambos serían capaces de lidiar con periodos de acidificación metabólica producida por hipoxia ambiental. Los niveles de LDH fueron excepcionalmente altos en el hígado, lo que podría relacionarse con factores ambientales como la contaminación ambiental. La baja razón MDH/LDH y la menor actividad de CS y ETS en el músculo, sumado a la alta actividad de LDH en el hígado indicarían un perfil metabólico de M. gayi gayi para tolerar condiciones de hipoxia y por lo tanto permanecer en la ZMO, pero disminuyendo su actividad natatoria.
\end{abstract}

Palabras clave: Merluccius gayi gayi, zona de mínimo oxígeno, actividad enzimática, hipoxia

\begin{abstract}
The Humboldt Current System (HCS), off the coast of Chile, has an Oxygen Minimum Zone (OMZ) between 30 and $250 \mathrm{~m}$ depth, with oxygen concentrations $<0.5 \mathrm{ml} \mathrm{L}^{-1}$. Densities of Merluccius gayi gayi associated with this zone are highest between 100 and $300 \mathrm{~m}$ depth, suggesting metabolic adaptations allowing it to remain in the OMZ. The aerobic and anaerobic potential of this demersal fish was estimated through the measurement of key metabolic enzymes and the electron transport system (ETS) of different body tissues (white muscle, heart, brain and liver). The activities of the citrate synthase (CS) enzyme and the ETS were higher in the brain and lower in muscle, confirming the predominance of aerobic metabolism in vital organs, different of muscle. The typical activity of the anaerobic enzyme lactate dehydrogenase (LDH) fluctuated between $55 \pm 17.5$ and $263 \pm 79 \mathrm{Ul} \mathrm{g}^{-1}$ wet weight, with lower activities in heart and brain. The low LDH activity and high MDH/LDH ratio found in these vital organs indicate that they are able to cope with metabolic acidification during long periods of environmental hypoxia. Exceptionally high LDH activity was found in the liver which may be related to environmental factors such as pollution. Considering the low MDH/LDH ratio of muscle, the decreased activity of CS and ETS in this tissue and the high LDH activity in the liver may indicate metabolic profile of M. gayi gayi in order to tolerate hypoxia, and therefore the capability to stay in the OMZ by decreasing its swimming activity.
\end{abstract}

Key words: Merluccius gayi gayi, minimum oxygen zone, enzymatic activity, hypoxia 


\section{INTRODUCTION}

Oxygen minimum zones are defined as regions where oxygen concentrations are lower than $0.5 \mathrm{ml} \mathrm{L}^{-1}$, and are typically found in the middle of the water column at depths between 10-1300 $\mathrm{m}$ (Levin 2003). These zones are usually formed in regions of strong upwelling, which generates high surface productivity that sinks and breaks down, decreasing the oxygen in the water column (Levin 2003).

In the Humboldt Current System (HCS), off the Chilean coast, low-oxygen conditions $\left(<0.5 \mathrm{ml} \mathrm{O}_{2} \mathrm{~L}^{-1}\right)$ can be found at depths as shallow as 30-50 $\mathrm{m}$ (northern Chile) and around 250 m (core; central-southern Chile) (Ahumada \& Chuecas 1979, Grados 1989), associated with wind-induced upwelling of lowoxygen, nutrient-rich Equatorial Subsurface Waters (ESSW) (Strub et al. 1998, Morales et al. 1999). This OMZ constitutes one of the largest in the world's oceans (Levin 2003, Quiñones et al. 2009) and is considered an important barrier for the vertical distribution of marine organisms (White 1988, Eissler \& Quiñones 1999, Escribano \& Hidalgo 2000, González \& Quiñones 2000, 2002; Ulloa et al. 2001, Gallardo et al. 2004). Hypoxia in coastal ecosystems has been recognized as an important system-level perturbation affecting both ecological dynamics and fishery sustainability around the globe (Grantham et al. 2004, Chan et al. 2008, Vaquer-Sunyer \& Duarte 2008), which may sometimes generate massive beaching and mortality of fish (Hernandez et al. 2010). Moreover, recent studies indicate that hypoxic zones are increasing worldwide, due to global warming and eutrophication (Diaz \& Rosenberg 2008, Stramma et al. 2010), making it increasingly important to understand the physiological and metabolic adjustments enabling the survival of species living in or near these hypoxic areas.

The biota dwelling permanently or semi-permanently in an OMZ must adapt to the low availability of oxygen (Childress \& Siebel 1998), using several strategies such as (i) more effective oxygen incorporation, (ii) reduced metabolic demands, and (iii) use of anaerobic metabolism (Childress \& Siebel 1998). It has been suggested that some vertically migrating species can alternate between anaerobic metabolism while in the $\mathrm{OMZ}$ and aerobic metabolism while in more oxygenated waters (Childress 1977). These species make an interesting object of study in terms of the biochemical and physiological adaptations that should evolve as a product of this environmental forcing. These adaptations consist largely of efficiently using anaerobic metabolic pathways for obtaining energy under hypoxic conditions, either environmental or physiological (González 2002).

Analyses of enzyme activities are used as an approach to look for greater reliance on anaerobic metabolism in OMZ species (Childress \& Siebel 1998). Lactate dehydrogenase (LDH), the terminal dehydrogenase in the production of lactate, is used as an indicator of muscle anaerobic capacity. In contrast, citrate synthase (CS) catalyzes the first step in the Kreb's cycle and is considered an index of muscle aerobic capacity (Hochachka \& Somero1984). The enzyme malate dehydrogenase $(\mathrm{MDH})$ maintains the redox balance during intense anaerobic catabolism (Hochachka \& Somero 1984, González 2002). The glycolytic enzymatic activity in white muscle, specifically LDH, is also a good marker of swimming capability and feeding strategies in fish (Sullivan \& Somero 1980), with higher activity in burst swimming fish where physiological hypoxia occurs in white muscle.

The common hake Merluccius gayi gayi (Guichenot, 1848), an important demersal resource, is found in the HCS off Chile and Peru (Arancibia 1997). It is an important commercial species in Chile (Arancibia \& Neira 2008), with an annual catch of 36,900 tons in 2013 (SERNAPESCA 2014), and is currently considered overexploited in Chilean waters (Gatica et al. 2015). Adults are distributed across the continental shelf and slope between 50 and $500 \mathrm{~m}$ deep, associated with the cold, saline and poorly oxygenated water mass of the ESSW (Avilés et al. 1979, Lillo et al. 2012, Gatica et al. 2015). The species exhibits daily migrations within the water column; with the adults feeding mostly on fish such as anchovy, Engraulis ringens, and benthic crustaceans (Gatica et al. 2015) from low-oxygen waters at the bottom of the continental shelf. As a result, the highest densities of this species are associated with oxygen concentrations between 0.5 and $1 \mathrm{ml} \mathrm{O}_{2} \mathrm{~L}^{-1}$, especially between $29^{\circ} 40^{\prime} \mathrm{S}$ and $35^{\circ} 10^{\prime} \mathrm{S}$ (north zone, Fig. 1) (Lillo et al. 2002, 2005 and 2012). This suggests that hake should have certain physiological or metabolic features allowing it to remain in the hypoxic zone.

In this study, the aerobic and anaerobic enzymatic activities of different tissues in $M$. gayi gayi have been measured in order to assess the biochemical capacity of this species to tolerate low oxygen conditions.

\section{MATERIALS AND METHODS}

\section{Collection AND PRESERVATION OF STUDY ANIMALS}

Specimens of $M$. gayi gayi were collected on the continental shelf off central-southern Chile (36 $48^{\circ}$ 'S- $\left.73^{\circ} 15^{\prime} \mathrm{W}\right)$. Samples $(n=30)$ were taken in April 2005 on board the artisanal vessel 'Princesa III', using gill-net fishing gear located between 100 and $300 \mathrm{~m}$ depth. 
a)

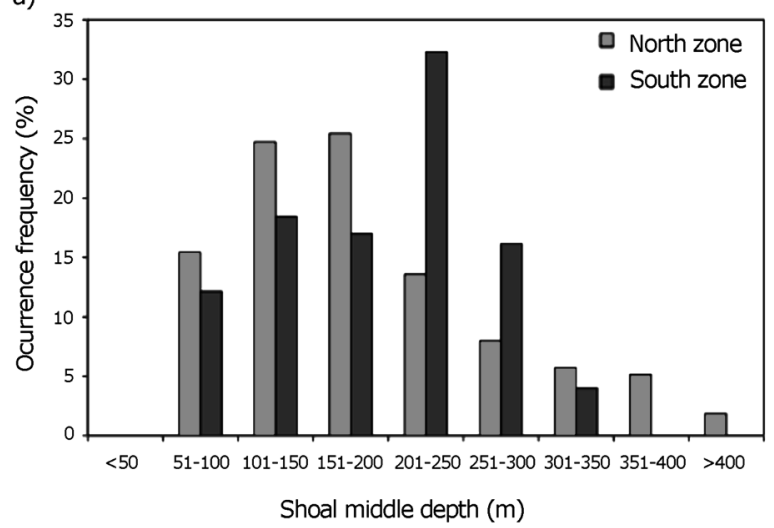

b)

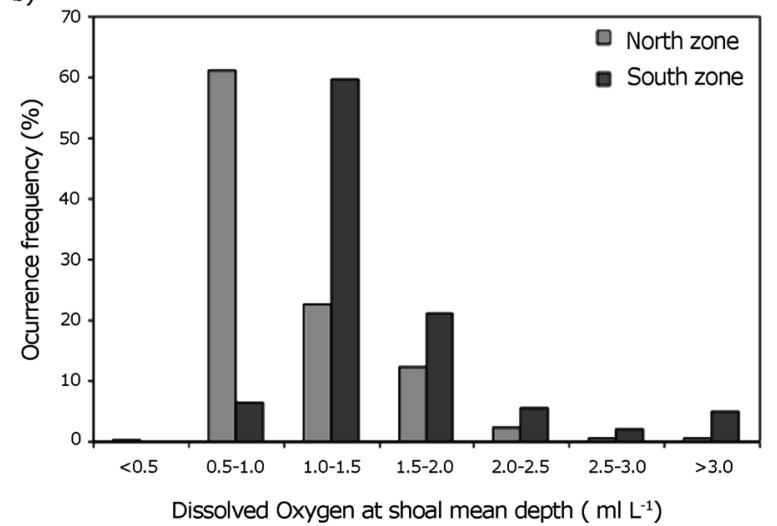

Figure 1. a) M ean depth of occurrence of $M$. gayi gayi shoals in northern and southern Chile; b) frequency of occurrence of $M$ gayi gayi within different oxygen concentration ranges (modified from Lillo et al. 2012) / a) Profundidad promedio de las agregaciones de M. gayi gayi en el norte y sur de Chile, b) frecuencia de ocurrencia de M. gayi gayi en diferentes rangos de concentración de oxígeno (modificado de Lillo et al. 2012)

Once caught, each live hake was sacrificed using a benzocaine overdose (100 mg L-1) (Barker et al. 2012) and then measured (fork length, FL). Immediately after, white muscle samples (approx. $1 \mathrm{~cm}^{3}$ ) were extracted from each individual from the dorsal area, behind the pectoral fin. Samples of liver, heart and brain tissue were also extracted. All samples were immediately stored in liquid nitrogen for later enzymatic analysis. The rest of the fish were kept on ice (less than $5 \mathrm{~h}$ ) until they were weighed in the laboratory on land.

\section{HoMOgENIZATION}

The samples were weighed and homogenized in $200 \mathrm{mM}$ $\mathrm{K}_{2} \mathrm{HPO}_{4}$ buffer ( $\mathrm{pH} 7.9$ ), $0.3 \%$ polyvynilpirrolidone (PVP), 5 mM EDTA, and $0.1 \%$ Triton X-100, using an Ultra Turrax homogenizer in an ice bath. The amount of buffer solution added to each sample was calculated using a dilution factor that varied according to the different tissues (1:40 for heart, muscle and brain; 1: 100 for liver). The homogenate was centrifuged for 5 min at $3000 \mathrm{~g}\left(4^{\circ} \mathrm{C}\right)$, and the supernatant used for the enzyme assays. One part of the supernatant was used for the ETS activity and the rest for measuring enzymatic activity.

\section{DETERMINATION OF ENZYMATIC ACTIVITY RELATED TO ANAEROBIC METABOLISM}

Measurements of the various enzyme activities were conducted by spectrophotometry and run in triplicate. Enzyme activities were expressed as $\mu$ moles of substrate converted per minute (IU) per gram of wet weight (ww). The average assay temperature was between $15^{\circ}$ and $16^{\circ} \mathrm{C}$.
Lactate pathway activity (LDH) was analyzed as representative of the anaerobic metabolism. The lactate pathway maintains the metabolic rate under environmental or physiological hypoxic conditions (Livingstone 1983).

The assay mixture was modified from Schiedek (1997) and contained an $80 \mathrm{mM} \mathrm{K}_{2} \mathrm{HPO}_{4}$ buffer (pH 7.9) and $3.2 \mathrm{mM}$ pyruvate. Before measuring, $0.2 \mathrm{mM} \mathrm{NADH}$ was added to the mixture. Finally, an aliquot of supernatant was added and the decay of the NADH absorption at $340 \mathrm{~nm}$ was measured. All the enzymatic activities were corrected for nonspecific NADH oxidation.

MDH activity, from oxaloacetate to malate, was measured in all tissues using the procedure described by Childress \& Somero (1979) and Vetter et al. (1994).

\section{DETERMINATION OF ENZYMATIC ACTIVITY RELATED TO AEROBIC METABOLISM}

The activity of the citrate synthase (CS) enzyme, characteristic of aerobic metabolism, was measured using a modified version of the method proposed by Childress \& Somero (1979) and Vetter et al. (1994). The reaction mixture contained $50 \mathrm{mM}$ Imidazol $/ \mathrm{HCl} \mathrm{pH} 8.0$ at $20^{\circ} \mathrm{C}, 1.5 \mathrm{mM} \mathrm{MgSO}_{4}, 0.1 \mathrm{mM}$ acid 5.5 ditiobis (2-nitrobenzoic) (DTNB), $0.06 \mathrm{mM}$ acetyl-CoA. The supernatant was added, and the mixture incubated for 20 $\mathrm{min}$ at room temperature. Afterward, $0.2 \mathrm{mM}$ of oxalacetate was added, and absorbance was measured. Absorbance was determined at $412 \mathrm{~nm}$. All the determinations were corrected using a blank containing the supernatant but with the absence of oxalacetate. 


\section{ELECTRON TRANSPORT SYSTEM (ETS) ACTIVITY}

The potential activity of the electron transport chain was determined using the ETS technique described by Packard (1971). This is an indirect enzymatic method used to estimate the rate of oxygen consumption as an expression of the maximum potential activity of the electron transporters in the respiratory chain at a mitochondrial level.

In situ ETS activity was calculated with the Arrhenius equation $\left[\mathrm{S}=\mathrm{A} \exp \left(\mathrm{E}_{\mathrm{a}} / \mathrm{k}\left(1 / \mathrm{T}_{\mathrm{a}}-1 / \mathrm{T}_{\mathrm{s}}\right)\right)\right]$, where $\mathrm{S}$ is the in situ ETS, A is the ETS calculated at the assay incubation temperature, $\mathrm{E}_{\mathrm{a}}$ is the Arrhenius activation energy, $\mathrm{k}$ is the constant of the gases $\left(1.987 \mathrm{cal} \mathrm{mol}^{-1} \mathrm{deg}^{-1}\right), \mathrm{T}_{\mathrm{a}}$ is the assay temperature $\left({ }^{\circ} \mathrm{K}\right)$, and $\mathrm{T}_{\mathrm{s}}$ is the in situ temperature $\left({ }^{\circ} \mathrm{K}\right)$. The activation energy used was $16.2\left(\mathrm{kcal} \mathrm{mol}^{-1}\right)$ (Arístegui \& Montero 1995). The in situ temperature was $10^{\circ} \mathrm{C}$, which corresponded to the temperature observed at $200 \mathrm{~m}$ depth, in the area where common hake are usually found (Lillo et al. 2002).

The conversion of ETS activity to oxygen consumption (R) was done using an ETS/R ratio of 2 (Ikeda 1996), based on the assumption that the kinetics of Michaelis-Menten can be applied to respiratory chemistry and that the concentration of the respiratory regulator (i.e., $\mathrm{ADP}$ ) remains near $\mathrm{Km}$.

All potential activities were expressed as apparent specific activities. The unit used to express LDH and MDH activity is $\mu \mathrm{mol} \mathrm{NADH} \mathrm{min}^{-1} \mathrm{~g} \mathrm{ww}^{-1}$. CS activity is expressed as $\mu \mathrm{mol}$ DTNB min $^{-1} \mathrm{~g} \mathrm{ww}^{-1}$ and ETS units as $\mu \mathrm{LO}_{2} \mathrm{~h}^{-1} \mathrm{~g} \mathrm{ww}^{-1}$.

\section{Statistical analysis}

A one-way analysis of variance (ANOVA) was used to evaluate differences in enzymatic activity among tissues, a Tukey post hoc test was performed to see which tissue differed. Regression analysis was conducted to explore the relationship between body weight and enzymatic activity.

\section{Results}

Body weight of $M$. gayi gayi specimens ranged from 263 and $861 \mathrm{~g}$. The enzymatic activities of both aerobic and anaerobic metabolisms are shown in Table 1, along with the activity of the electron transport system (ETS).

\section{Aerobic metabolism}

CS activities ranged between $0.741 \pm 0.19$ and $2.302 \pm 0.49$ $\mu \mathrm{mol}$ DTNB $\min ^{-1} \mathrm{~g} \mathrm{ww}^{-1}$ (Table 1 ), with the lowest activity corresponding to the muscle $\left(\mathrm{F}_{3}=30.55, P<0.01\right)$, whereas the other tissues showed more similar activities between them (Fig. 2c). The activity of the electron transport system (ETS) ranged from $135 \pm 74$ to $872 \pm 298 \mu 1 \mathrm{O}_{2} \mathrm{~h}^{-1} \mathrm{~g}^{-1} \mathrm{ww}$ (Table 1), also with a lower activity in white muscle (Fig. 3d) $\left(\mathrm{F}_{3}=27.46\right.$, $P<0.01)$.

A significant positive and linear relationship $(P<0.05)$ was found between the log transformed body weight and $\log$ ETS activity in the liver of M. gayi gayi (Fig. 4).

\section{AnAERobic MEtabolism}

The LDH activity fluctuated between $55.1 \pm 17.5$ and $263 \pm$ $79 \mu \mathrm{mol} \mathrm{NADH} \min ^{-1} \mathrm{~g}^{-1} \mathrm{ww}$ (Table 1, Fig. 2a), with significant differences between tissues (one-way ANOVA, $\mathrm{F}_{3}=78.17, P$ $<0.01)$ and higher activity in the liver, followed by heart, muscle, and finally brain.

\begin{tabular}{|c|c|c|c|c|c|c|c|c|}
\hline & $\mathrm{n}$ & Muscle & $\mathrm{n}$ & Liver & $\mathrm{n}$ & Brain & $\mathrm{n}$ & Heart \\
\hline $\mathrm{LDH}$ & 16 & $61.1 \pm 24$ & 13 & $263 \pm 79$ & 14 & $55.1 \pm 17.5$ & 14 & $73.7 \pm 16$ \\
\hline $\mathrm{MDH}$ & 16 & $35.05 \pm 10.6$ & 13 & $184 \pm 55.3$ & 13 & $190.76 \pm 43$ & 13 & $141.2 \pm 44$ \\
\hline $\mathrm{CS}$ & 17 & $0.741 \pm 0.19$ & 9 & $1.776 \pm 0.84$ & 11 & $2.302 \pm 0.49$ & 12 & $1.829 \pm 0.23$ \\
\hline ETS & 43 & $135 \pm 74$ & 30 & $807.4 \pm 381$ & 10 & $872 \pm 298$ & 11 & $713.04 \pm 269.4$ \\
\hline $\mathrm{R}$ & 43 & $67.5 \pm 37$ & 30 & $403.7 \pm 191$ & 10 & $436 \pm 148$ & 11 & $356.5 \pm 134.7$ \\
\hline
\end{tabular}



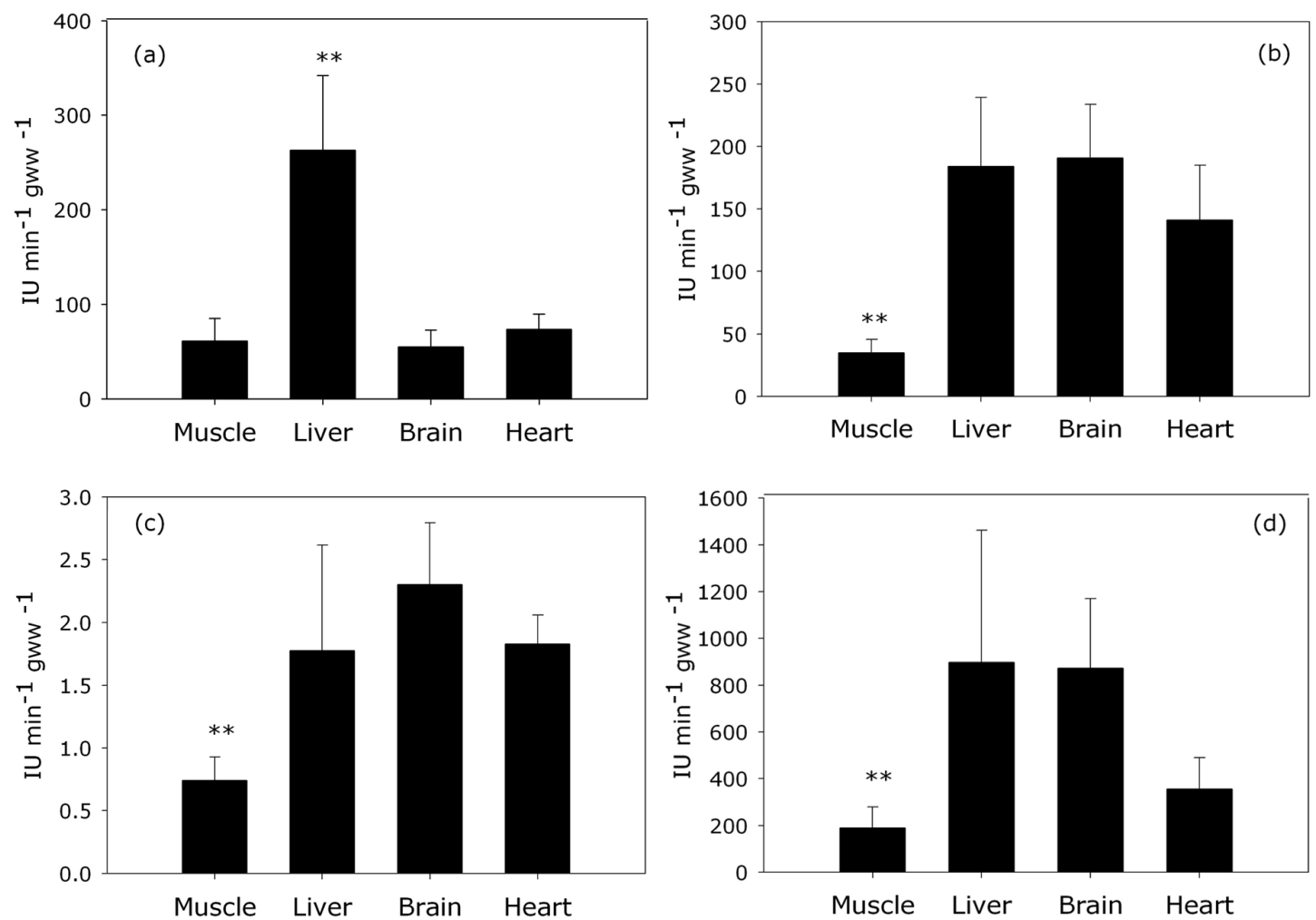

Figure 2. Mean enzyme and electron transport system activity in different tissues of M. gayi gayi. (a) LDH, (b) M DH, (c) CS, (d) ETS. Values are means \pm SD. Significant differences between tissues are given by $* *(\mathbf{P}<\mathbf{0 . 0 1})$ / Promedio de la actividad enzimática de enzimas y del sistema de transporte de electrones en los tejidos de M. gayi gayi. (a) LDH, (b) MDH, (c) CS, (d) ETS. Valores son medias \pm DE. Diferencias significativas entre tejidos se presentan $\operatorname{con}^{* *}(\mathrm{P}<0,01)$

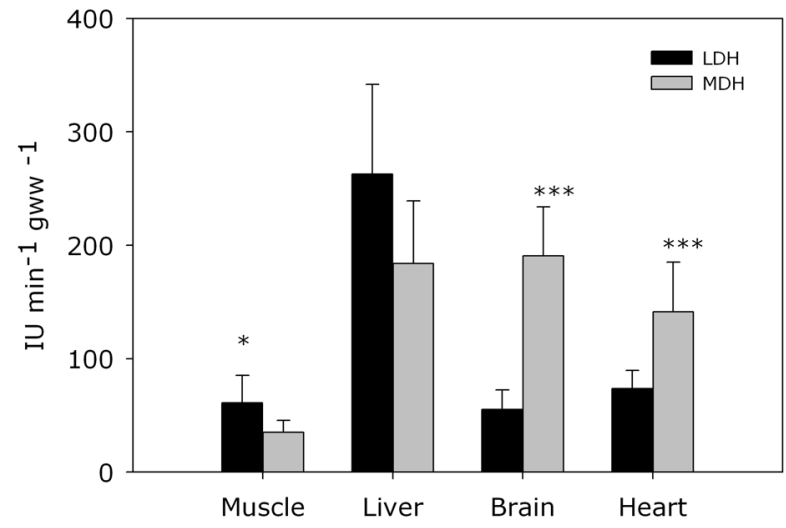

Figure 3. Mean lactate dehydrogenase (LDH) and malate dehydrogenase (MDH) activity of different tissues from M. gayi gayi. Values are means \pm SD. Significant differences between enzymes are given by $*(\mathbf{P}<0.05), * * * \mathbf{P}<0.0001) /$ Actividad media de lactato deshidrogenasa $(\mathrm{LDH})$ y malato deshidrogenasa $(\mathrm{MDH})$ en diferentes tejidos de M. gayi gayi. Valores son medias $\pm D E$. Diferencias significativas entre tejidos se presentan $\operatorname{con}^{*}(P<0,05)$ y ${ }^{* * *}(P<$ $0,0001)$

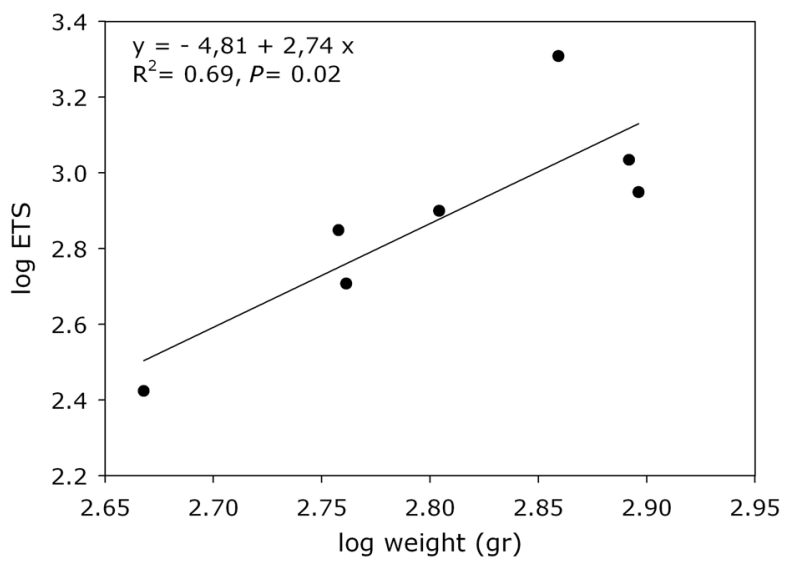

Figure 4. Relationship between body weight of $M$. gayi gayi and ETS $\left(\mu / \mathrm{O}_{2} \mathrm{~h}^{-1} \mathbf{g}^{-1}\right.$ wet tissue) in liver $(\mathrm{P}<0.05) /$ Relación entre peso corporal de $\mathrm{M}$. gayi gayi y ETS $\left(\mu \mathrm{O} \mathrm{O}_{2} \mathrm{~h}^{-1} \mathrm{~g}^{-1}\right.$ tejido húmedo) en hígado $(\mathrm{P}<0,05)$ 
Table 2. MDH/ LDH ratio for different tissues in M. gayi gayi / Razón MDH/LDH para diferentes tejidos de M . gayi gayi

\begin{tabular}{lc}
\hline & MDH/ LDH \\
\hline Muscle & 0.666 \\
Liver & 0.703 \\
Brain & 3.737 \\
Heart & 2.024 \\
\hline
\end{tabular}

a)

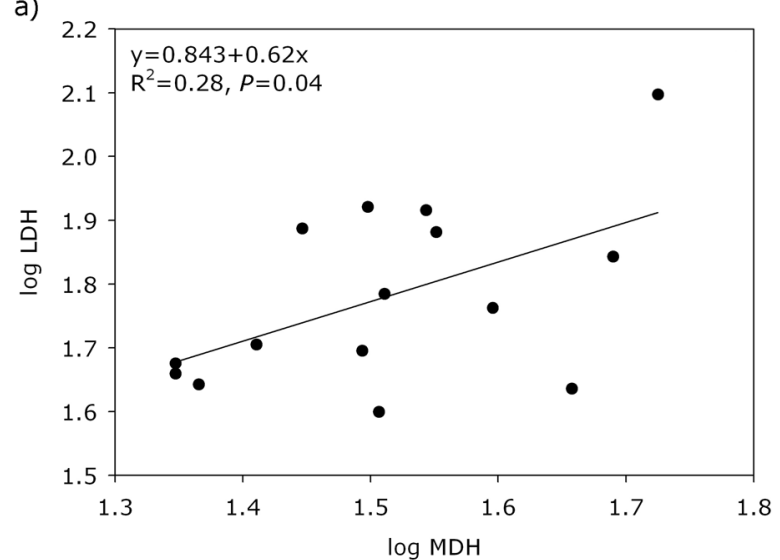

b)

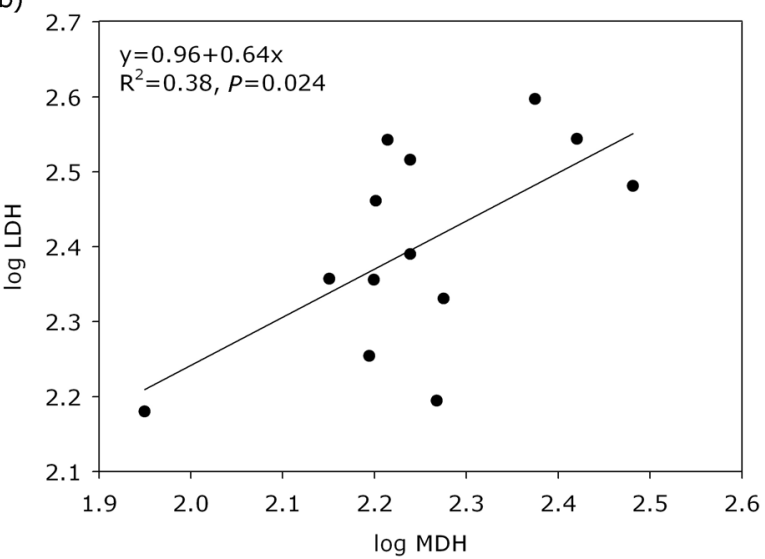

Figure 5. M DH-LDH relationship in: a) muscle and $b$ ) liver of $M$. gayi gayi / Relación entre MDH y LDH en: a) músculo blanco y b) hígado de M. gayi gayi
MDH ranged between $35.1 \pm 11$ and $191 \pm 43 \mu$ mol NADH $\mathrm{min}^{-1} \mathrm{~g}^{-1} \mathrm{ww}$ (Table 1, Fig. 2b), and was significantly lower (one-way ANOVA, $\mathrm{F}_{3}=47.2, P<0.01$ ) in white muscle than among the other tissues. The MDH activity pattern in different tissues was fairly similar to that observed for CS andETS (Figs. 2c,d), and its activity was higher than LDH in heart and brain (Fig. 3) (one-way ANOVA, $\mathrm{F}_{3}=49.93, P<0.01$ ).

The MDH/LDH ratio was calculated in order to indicate which type of metabolism is preponderant in each tissue. This ratio was greater than 1 in the brain and heart, and less than 1 in muscle and liver (Table 2), due to the high levels of LDH in the former two tissues. A slight significant positive relationship $(P<$ 0.05 ) was found between log transformed $\mathrm{MDH}$ and $\log$ transformed LDH in the muscle and liver of M. gayi gayi (Fig. $5)$.

\section{DisCUSSION}

Merluccius gayi gayi is a typical demersal species of centralsouthern coastal Chile, distributed from surface to $500 \mathrm{~m}$ depth (Lillo et al. 2005). It feeds primarily on benthic organisms (squat lobster) and euphausiids (Vidal et al. 1997, Arancibia 1997, Gatica et al. 2015) over the continental shelf. The anaerobic metabolic capacity detected in the present study is consistent with both the vertical distribution and the trophic behaviour of the species, as both characteristics require an adaptive capacity for remaining, for periods of at least a few hours, in waters of the oxygen minimum zone $\left(\leq 0.5 \mathrm{ml} \mathrm{O}_{2} \mathrm{~L}^{-1}\right)$.

Lower CS and ETS activities found in the muscle contrast with the high values found in all other tissues. This support the predominance of aerobic metabolism in all the tissues except muscle, agreeing with other studies carried out on fish (Childress \& Somero 1979, Yang et al. 1992, Panepucci et al. 2000, Panepucci et al. 2001, Treberg et al. 2003) and most vertebrates (Hochachka \& Somero 1973).

LDH activity was very high in hake liver, followed by lessening activity in heart, muscle, and, finally, brain. The activities of $\mathrm{LDH}$

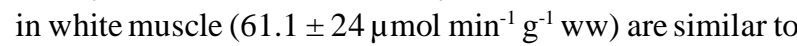
those determined in deep-sea fish (Saavedra et al. 2016), and lower than in shallow living species which are more continuous swimmers, such as mackerel (Sullivan \& Somero 1980). The similarity of this LDH activity with that of other deep living species may also be related to a decreased capacity for carbohydrate metabolism, which in turn has been related to a reduction in growth or swimming activity during chronic hypoxia (Martinez et al. 2006). Nevertheless, M. gayi gayi has almost exclusively white muscle in its body which powers rapid burst swimming movement for prey capture and predator avoidance, consistent with the low CS andETS activity in this tissue (Table 
1). This burst swimming capacity was described by Queirolo et al. (2010) through direct observations of hake behaviour in response to trawling. On the other hand, the higher activities of LDH in liver agree with the increased specific activities found by Martinez et al. (2006) in the liver of Fundulus grandis acclimatized to hypoxic conditions. They suggest that this increase in carbohydrate metabolism in liver is a result of 'chronic hypoxia', which is consistent with the normal presence of $M$. gayi gayi in the OMZ (Lillo et al. 2012).

MDH activities in the liver, brain, and heart were very similar, revealing a potential anaerobic metabolism in these organs under prolonged periods of low-oxygen conditions, preventing lactic acid accumulation (Shapiro \& Bobkova 1975, Panepucci et al. 2000). In contrast, white muscle shows very low levels of MDH activity, which suggests that $M$. gayi gayi adjusts its metabolism toward efficient anaerobic production of ATP and the use of LDH to maintain cytoplasmic NAD/NADH (Chippari-Gomez et al. 2003). This is also observed in the different $\mathrm{MDH} / \mathrm{LDH}$ ratios between tissues, where white muscle showed the lowest, while brain and heart both had ratios higher than 1 , indicating that attenuated pyruvate to lactate flux is produced in these tissues and, as a consequence, carbohydrate metabolism will be largely channelled toward complete oxidation (Almeida-Val \& Hochachka 1995 sensu Panepucci et al. 2000). These results agree with Panepucci et al. (2000), who found an extremely high $\mathrm{MDH} / \mathrm{LDH}$ ratio for the heart of the fish Rhinelepis strigosas, showing the importance of this organ to fish survival in critically hypoxic situations. In brief, the high $\mathrm{MDH} / \mathrm{LDH}$ ratio found in the heart and brain of M. gayi gayi, suggests that hake present metabolic adaptations that allow them to tolerate low-oxygen conditions by protecting their vital organs from prolonged periods of hypoxia. Despite the low MDH/ LDH ratio found in muscle and liver, it is possible to see a slight correlation between both enzymes in these tissues (Fig. 5) which suggests that both enzymatic activities could be acting simultaneously during chronic hypoxia, as it has been observed in bivalves during extreme anoxic stress (Grandón et al. 2008). Also, the much higher activity of MDH relative to CS in both tissues suggests that, in addition to its function in the citric acid cycle, MDH may play an important role in redox balance in $M$. gayi gayi white muscle tissue.

In relation to the size dependence of enzymatic activities, only liver ETS activity showed an increase with body mass. However, these results may not be conclusive because of the low sample number. This is also the explanation for the absence of size dependence in the other tissues.

From the few enzymatic indicators obtained in the present study, it is possible to affirm that M. gayi gayi has a metabolic profile to tolerate hypoxic conditions, and therefore the capability to stay in the OMZ, maintaining slow swimming activity, but with the possibility for burst swimming when necessary.

It is important to highlight the elevated LDH activity found in M. gayi gayi liver, which does not agree with the typically low activity of this enzyme in this organ observed in other fish species (e.g., Panepucci et al. 2001, Cooper et al. 2002), and with the belief that this organ is considered a predominantly aerobic tissue with high blood irrigation (Hinton et al. 2009). These high LDH levels could be an indication of metabolic failure of the liver (Orrego et al. 2010) due to the exposure of M. gayi gayi to pollution sources (industrial waste and domestic sewage) associated with the Biobío river and the coastal zones of centralsouthern Chile (e.g., Parra et al. 1993, Riveros et al. 1996, Muñoz 2002), also demonstrated by other studies (Monteiro et al. 2007, Orrego et al. 2011). Further research is needed to explore this hypothesis.

\section{ACKNOWLEDGEMENTS}

This research was funded by the Interdisciplinary Center for Aquaculture Research (INCAR; FONDAP Project N 15110027; CONICYT). L. Saavedra was also supported by FONDECYT N $\mathrm{N}^{\circ} 3150392$ and by the Center for the study of multiple-drivers on marine socio-ecological systems (MUSELS, NC-120086). R. González received additional funding from COPAS Sur-Austral CONICYT PIA PFB31 of Universidad de Concepción. We would like to thank Gerdhard Jessen and Marcelo Pavez for their help during field work.

\section{LITERATURE CITED}

Ahumada R \& L Chuecas. 1979. Algunas características hidrográficas de la Bahía Concepción ( $36^{\circ} 40^{\prime}$ S , 7302'W) y áreas adyacentes (Chile). Gayana 8: 1-56.

Arancibia H. 1997. Evaluación de la demanda de alimento en merluza común y análisis de su impacto en pre-reclutas. Informes Técnicos FIP, FIP-IT 95-17: 1-131. Universidad de Concepción, Concepción. <http://www.fip.cl/Archivos/ Hitos/Informes/inffinal\%2095-17.pdf>

Arancibia H \& S Neira. 2008. Overview of the Chilean hake (Merluccius gayi) stock, a biomass forecast, and the jumbo squid (Dosidicus gigas) predator-prey relationship off central Chile $\left(33^{\circ} \mathrm{S}-39^{\circ} \mathrm{S}\right)$. CalCOFI Report 49: 104-115.

Arístegui J \& MF Montero. 1995. The relationship between community respiration and ETS activity in the ocean. Journal of Plankton Research 17: 1563-1571.

Avilés S, M Aguayo, F Hinostroza \& J Cañón. 1979. Merluza común Merluccius gayi (Guichenot). En: Estado actual de las principales pesquerías nacionales: Bases para un desarrollo pesquero. Vol I (Peces). Instituto de Fomento Pesquero, Valparaíso, CORFO AP79-18: 1-37. 
Barker D, GL Allan, SJ Rowland \& JM Pickles. 2002. A guide to acceptable procedures and practices for aquaculture and fisheries research, $52 \mathrm{pp}$. NSW Fisheries Animal Care and Ethics Committee, Port Stephens Fisheries Centre, New South Wales.

Chan F, JA Barth, J Lubchenco, A Kirincich, H Weeks, WT Peterson \& BA Merge. 2008. Emergence of anoxia in the California Current Large Marine Ecosystem. Science 319:920

Childress JJ. 1977. Effects of pressure, temperature and oxygen on the oxygen consumption rate of the midwater copepod Gaussia princeps. Marine Biology 39: 19-24.

Childress JJ \& GN Somero. 1979. Depth-related enzymatic activities in muscle, brain and heart of deep-living pelagic marine teleosts. Marine Biology 52: 273-283.

Childress JJ \& BA Seibel. 1998. Life at stable low oxygen levels: adaptations of animals to oceanic oxygen minimum layers. Journal of Experimental Biology 201: 1223-1232.

Chippari-Gómez AR, MA Leitao, MN Paula-Silva, LS Mesquita-Saad \& VM Almeida-Val. 2003. Metabolic adjustments in Satanoperca aff. jurupari (Perciformes: Cichlidae) Genetics and Molecular Biology 26(1): 27-32.

Cooper RU, MA Farwell, LM Clough \& TL West. 2002. Hypoxia-induced metabolic and antioxidant enzymatic activities in the estuarine fish Leiostomus xanthurus. Journal of Experimental Marine Biology and Ecology 279: 1-20.

Diaz RJ \& R Rosenberg. 2008. Spreading dead zones and consequences for marine ecosystems. Science 321: 926-929.

Eissler Y \& RA Quiñones. 1999. Microplanktonic respiration off northern Chile during El Niño 1997-1998. Journal of Plankton Research 21:2263-2283.

Escribano R \& P Hidalgo. 2000. Spatial distribution of copepods during coastal upwelling in a northern area of the Eastern Boundary Humboldt Current. Journal of the Marine Biological Association of the United Kingdom 80: 283-290.

Gallardo VA, M Palma, F Carrasco, D Gutiérrez, LA Levin \& JI Cañete. 2004. Macrobenthic zonation caused by the oxygen minimum zone on the shelf and slope off central Chile. Deep-Sea Research II 51: 2475-2490.

Gatica C, S Neira, H Arancibia \& S Vásquez. 2015. The biology, fishery and market of Chilean hake (Merluccius gayi gayi) in the Southeastern Pacific Ocean. In: Arancibia $\mathrm{H}$ (ed). Hakes: Biology and exploitation. Fish and Aquatic Resources Series 17: 127-149. John Wiley \& Sons, Chichester.

González RR. 2002. Actividad enzimática catabólica en las comunidades planctónicas y bentónicas asociadas a la zona de mínimo oxígeno en el sistema de la corriente de Humboldt. Tesis de Doctorado en Oceanografía, Universidad de Concepción, Concepción, 221 pp.

González R \& RA Quiñones. 2000. Pyruvate oxidoreductases involved in glycolytic anaerobic metabolism of polychaetes from the continental shelf off central-south Chile. Estuarine, Coastal and Shelf Science 51: 507-519.
González RR \& RA Quiñones. 2002. LDH activity in Euphausia mucronata and Calanus chilensis: implications for vertical migration behavior. Journal of Plankton Research 24(12): 1349-1356.

Grados MC. 1989. Variabilidad del régimen hídrico del codo peruano-chileno. Memorias del Simposio Internacional de los Recursos Vivos y las Pesquerías en el Pacífico Sudeste. CPPS Revista Pacífico Sur, Número Especial: 95-105.

Grandón M, J Barros \& RR González. 2008. Metabolic characterization of Diplodon chilensis (Gray, 1828) (Bivalvia: Hyriidae) exposed to experimental anoxia. Revista de Biología Marina y Oceanografía 43(3): 531-537.

Grantham BA, F Chan F, KJ Nielsen, DS Fox, JA Barth, A Huyer, J Lubchenco \& BA Menge. 2004. Upwellingdriven nearshore hypoxia signals ecosystem and oceanographic changes in the northeast Pacific. Nature 429(6993): 749-754.

Hernandez-Miranda E, RA Quiñones, G Aedo, A Valenzuela, N Mermoud, C Román \& F Yañez. 2010. A major fish stranding caused by a natural hypoxic event in a shallow bay of the eastern South Pacific Ocean. Journal of Fish Biology 76: 1543-1564.

Hinton D, H Segner, DWT Au, SW Kullman \& RC Hardman. 2009. Key target system and organismal effects: liver toxicity. In: Di Guilio R \& D Hinton (eds). The toxicology of fishes, pp. 327-400. CRC Press, Taylor \& Francis Group, New York.

Hochachka PW \& GN Somero. 1973. Strategies of biochemical adaptation, 357 pp. W.B. Saunders Company, Philadelphia.

Hochachka PW \& GN Somero. 1984. Biochemical adaptation: Mechanism and process in physiological evolution, $538 \mathrm{pp}$. Princeton University Press, Princeton.

Ikeda T. 1996. Metabolism, body composition, and energy budget of the mesopelagic fish Maurolicus muelleri in the Sea of Japan. Fishery Bulletin 94: 49-58.

Levin LA. 2003. Oxygen minimum zone benthos: adaptation and community response to hypoxia. Oceanography and Marine Biology: An Annual Review 41: 1-45.

Lillo S, S Nuñez, V Ojeda, F Balbontín, M Braun, $R$ Tascheri, A Saavedra, R Bravo, L Cubillos \& J Olivares. 2002. Evaluación hidroacústica del recurso merluza común en la zona centro-sur, 2000. Informe Final, Fondo Investigación Pesquera FIP, 2001-18: 1-379. Instituto de Fomento Pesquero, Valparaíso. <http://www.fip.cl/Archivos/ Hitos/Informes/inffinal\%202001-18.pdf>

Lillo S, J Olivares, M Braun, E Díaz, S Núñez, A Saavedra, J Saavedra \& R Tascheri. 2005. Evaluación hidroacústica de merluza común, año 2004. Informe Final, Proyecto FIP 2004-09: 1-395. Instituto de Fomento Pesquero, Valparaíso. <http://www.fip.cl/Archivos/Hitos/Informes/ inffinal\%202004-09.pdf> 
Lillo S, R Bahamonde, J Olivares, JC Saavedra, E Molina, E Ramos, M Rojas, E Díaz, M Braun, J Angulo, V Valenzuela, S Nuñez, S Vázquez, A Sepúlveda, S Soto \& A Saavedra. 2012. Evaluación hidroacústica de merluza común, año 2012. Informe Final, FIP N ${ }^{\circ}$ 2012-04: 1-430. Instituto de Fomento Pesquero, Valparaíso. <http:// w w w.fip.cl/Archivos/Hitos/Informes / INFORME\%20HITO\%20FINAL1055Adjunto1.pdf>

Livingstone DR. 1983. Invertebrate and vertebrate pathways of anaerobic metabolism: evolutionary considerations. Journal of the Geological Society, London 140:27-37.

Martinez ML, Ch Landry, R Boehm, S Manning, AO Cheek \& BB Rees. 2006. Effects of long-term hypoxia on enzymes of carbohydrate metabolism in the Gulf killifish, Fundulus grandis. The Journal of Experimental Biology 209: 3851-3861.

Monteiro M, C Quintaneiro, AJ Nogueira, F Morgado, AM Soares \& L Guilhermino. 2007. Impact of chemical exposure on the fish Pomatoschistus microps Kroyer (1983) in estuaries of the Portuguese Northwest coast. Chemosphere 66(3): 514-522.

Morales CM, S Hormazabal \& JL Blanco. 1999. Interannual variability in the mesoscale distribution in the depth of the upper boundary of the oxygen minimum layer off northern Chile (18-24 $\left.{ }^{\circ} \mathrm{S}\right)$ : Implications for the pelagic system and biogeochemical cycling. Journal of Marine Research 57: 909932.

Muñoz P. 2002. Evaluación de las vías de transporte de plomo total en un área costera de Chile central a través de un balance geoquímico. Doctorate Thesis, Postgraduate Program in Oceanography, Department of Oceanography, Universidad de Concepción, Concepción, 192 pp.

Orrego R, Z Pandelides, J Guchardi \& D Holdway. 2010. Effects of pulp and paper mill effluents extracts on liver anaerobic and aerobic metabolic enzymes in rainbow trout. Ecotoxicology and Environmental Safety 74: 761-768.

Packard TT. 1971. The measurement of respiratory electrontransport activity in marine phytoplankton. Journal of Marine Research 29(3): 235-244.

Panepucci L, MN Fernandes, JR Sanches \& FT Rantin. 2000. Changes in lactate dehydrogenase activities during hypoxia and after temperature acclimation in the armored fish, Rhinelepis strigosa (Siluriformes, Loricariidae). Brazilian Journal of Biology 60(2): 353-360.

Panepucci RA, L Panepucci, MN Fernandez, JR Sanchez \& FT Rantin. 2001. The effect of hypoxia and recuperation on carbohydrate metabolism in Pacu (Piaractus mesopotamicus). Brazilian Journal of Biology 61(4): 547554.

Parra O, L Chuecas, H Campos, M Vighi \& R Vismara. 1993. Caracterízación física y química y evaluación de la calidad para uso múltiple del agua del río Bío Bío (Chile Central). En: Faranda F \& O Parra (eds). Evaluación de la calidad del agua y ecología del sistema limnético y fluvial del río Bío Bío. Serie Monografías Científicas 2: 15-159. Centro EULA, Universidad de Concepción, Concepción.
Queirolo D, I Montenegro, E Gaete \& G Plaza. 2010. Direct observation of Chilean hake (Merluccius gayi gayi) behaviour in response to trawling in a South Central Chilean fishery. Fisheries Research 102: 327-329.

Quiñones RA, HA Levipan \& H Urrutia. 2009. Spatial and temporal variability of planktonic archaeal abundance in the Humboldt System off Chile. Deep Sea Research II 56(16): 1073-1082.

Riveros A, L Troncoso, J Silva, E Soto, A Cifuentes, H Gaete, E Bay-Schmith \& A Larraín. 1996. Calidad ecotoxicológica de aguas receptoras de efluentes de industrias pesqueras. Un análisis sinóptico de efectos sobre varias especies, con aguas de Coronel, San Vicente y Rocuant (Región del Bio Bio, Chile). Gayana Oceanológica 4(2): 7791.

Saavedra L, RA Quiñones, RR González \& EJ Niklitschek. 2016. Aerobic and anaerobic enzymatic activity of orange roughy (Hoplostethus atlanticus) and alfonsino (Beryx splendens) from the Juan Fernandez seamount area. Fish Physiology and Biochemistry 42: 869-882. < doi 10.1007/ s10695-015-0181-3>

Schiedeck D. 1997. Marenzelleria viridis (Verril, 1873) Polychaeta, a new benthic species within European coastal waters, some metabolic features. Journal of Experimental Biology and Ecology 211: 85-101.

SERNAPESCA. 2014. Anuario estadístico de pesca 2013. Servicio Nacional de Pesca y Acuicultura,Valparaíso. <http:/ /www.sernapesca.cl/index.php? option $=$ com_content\& view=article \&id=1806:anuario-estadistico-de-pesca-2013>

Shapiro AZ \& AN Bobkova. 1975. The role of malate dehydrogenase in adaptation to hypoxia in invertebrates. Journal of Evolutionary Biochemistry and Physiology 11:478479.

Stramma L, S Schmidtko, LA Levin \& GC Johnson. 2010. Ocean oxygen minima expansions and their biological impacts. Deep Sea Research I 57(4): 587-595. <doi:10.1016/ j.dsr.2010.01.005>

Strub PT, JM Mesias, V Montecino, J Rutllant \& S Salinas. 1998. Coastal ocean circulation off western South America. In: Robinson AR \& KH Brink (eds). Ideas and observations on progress in the study of the seas, The Sea 11: 273-314. John Wiley, New York.

Sullivan KM \& GN Somero. 1980. Enzyme activities of fish skeletal muscle and brain as influenced by depth of occurrence and habits of feeding and locomotion. Marine Biology 60: 91-99.

Treberg JR, RA Martin \& WR Driedzic. 2003. Muscle enzyme activities in a deep-sea squaloid shark, Centroscyllium fabricii, compared with its shallow-living relative, Squalus acanthias. Journal of Experimental Zoology. Part A, Comparative Experimental Biology 300(2): 133-139. 
Ulloa O, R Escribano, S Hormazabal, RA Quiñones, RR González \& M Ramos. 2001. Evolution and biological effects of the 1997-98 El Niño in the upwelling ecosystem off northern Chile. Geophysical Research Letters 28: 15911594.

Vaquer-Sunyer R \& CM Duarte. 2008. Thresholds of hypoxia for marine biodiversity. PNAS 105(40): 15452-15457.

Vetter RD, EA Lynn, M Garza \& AS Costa. 1994. Depth zonation and metabolic adaptation in Dover sole, Microstomus pacificus, and other deep-living flatfishes: Factors that affect the sole. Marine Biology 120: 145-159.
Vidal R, E Acuña \& M Rey-Méndez. 1997. Dieta de la merluza Merluccius gayi (Guichenot, 1848) del norte de Chile. Boletín Instituto Español de Oceanografía 13(1 y 2): $35-45$.

White BN. 1988. Oceanic anoxic events and allopatric speciation in the deep sea. Biological Oceanography 5: 243259.

Yang TH, NC Lai, JB Graham \& GN Somero. 1992. Respiratory, blood and heart enzymatic adaptations of Sebastolobus alascanus (Scorpaenidae; Teleostei) to the oxygen minimum zone: a comparative study. The Biological Bulletin 183:490-499.

Received 14 March 2016 and accepted 5 September 2016

Associate Editor: Mauricio Landaeta D. 